\title{
Vitamin D3 Analogue ILX23-7553
}

National Cancer Institute

\section{Source}

National Cancer Institute. Vitamin D3 Analogue ILX23-7553. NCI Thesaurus. Code C1883.

A vitamin D3 analogue with potential antineoplastic activity. ILX23-7553 binds to and activates the vitamin $\mathrm{D}$ receptor, a cytoplasmic polypeptide expressed in normal vitamin D responsive tissues, but also overexpressed in certain cancers including hepatocellular carcinoma and pancreatic cancer. Mediated through vitamin D receptor, this agent induces cancer cell differentiation, inhibits cancer cell growth and induces apoptosis. In addition, ILX23-7553 may also induce growth arrest and apoptosis independent of vitamin $\mathrm{D}$ receptor activation through mechanisms that are not fully elucidated. 